\title{
Contribution of Workload and Compensation to Teacher's Burnout
}

\author{
Masduki Ahmad, Heni Rochimah 2 \\ DOI: 10.35445/alishlah.v13i1.367
}

\begin{abstract}
Article Info
Abstract

Keywords: Workload Compensation Burnout

This research was conducted to show the contribution of workload and compensation to teacher burnout in Cilacap Regency. The methodology in this study is the quantitative approach with multiple linear regression models. The sample was conducted on 142 teachers in Cilacap Regency. The research instrument is a closed questionnaire on google form based on the Likert scale. Hypothesis testing is obtained from the t-test and the F test. The results show several conclusions: 1) Workload contributes positively and significantly to teacher's burnout in Cilacap Regency, which means increasing workload will increase teacher's burnout. 2) Compensation has a negative and significant contribution to teacher work burnout in Cilacap Regency, which means an increase in compensation will decrease teacher work burnout. 3) Workload and compensation contribute to teacher work burnout in Cilacap Regency with a determination coefficient value of 0.439 or $43.9 \%$, which means that workload and compensation contribute together to burnout by $43.9 \%$.
\end{abstract}

Kata kunci:

Beban Kerja

Kompensasi

Kejenuhan Kerja

\begin{abstract}
Abstrak
Penelitian ini dilakukan untuk menunjukkan adanya kontribusi beban kerja dan kompensasi terhadap kejenuhan kerja guru di Kabupaten Cilacap. Metodologi dalam penelitian ini menggunakan pendekatan kuantitatif model regresi linier berganda. Sampel dilakukan terhadap 142 orang guru di Kabupaten Cilacap. Instrumen penelitian berupa angket tertutup dalam google form berdasarkan skala likert. Pengujian hipotesis didapat dari uji-t dan uji F. Hasil menunjukkan terdapat beberapa kesimpulan yaitu: 1) beban kerja berkontribusi positif dan signifikan terhadap kejenuhan kerja guru di Kabupaten Cilacap, artinya, meningkatnya beban kerja akan meningkatkan kejenuhan kerja pada guru. 2) kompenasi berkontribusi negatif dan signifikan terhadap kejenuhan kerja guru di Kabupaten Cilacap, dimana meningkatnya kompensasi akan membuat kejenuhan kerja guru menurun. 3) beban kerja dan kompensasi berkontribusi terhadap kejenuhan kerja guru di Kabupaten Cilacap dengan nilai koefisien determinasi sebesar 0.439 atau 43.9\%, artinya, beban kerja dan kompensasi secara bersama-sama memberikan kontribusi terhadap kejenuhan kerja sebesar $43.9 \%$.
\end{abstract}

\section{INTRODUCTION}

The role of teachers in the successful delivery of education is crucial. Teachers have the main task of educating, teaching, guiding, directing, training, assessing, and evaluating students,

\footnotetext{
${ }^{1}$ State University of Jakarta, Jakarta, Indonesia

Email: masduki@unj.ac.id

2 As-Syafiiyah Islamic University, Bekasi, Indonesia

Email: henirochimah.fkip@uia.ac.id

Vol.13(1) June, 2021

Received: February 2, 2021; Received in revised form: February 4, 2021; Accepted: February 17, 2021; Available online: March 30, 2021

This is an open access article under a Creative Commons Attribution-NonCommercial-ShareAlike 4.0 International License.
} 
which are listed in Government Regulation No. 74 of 2008. Teacher work directly related to students causes teachers to face many problems in carrying out their duties. Changes in education that are not planned systematically generate more and more teacher assignments and teachers' higher expectations (Wardhani, 2012). Other supporters such as additional facilities and infrastructure, teacher welfare have not changed. Thus, teachers can feel depressed, uncomfortable, and dissatisfied with the work done, known as the burnout phenomenon.

Burnout is an excessive response to chronic emotional reactions and interpersonal stress at work and is defined by emotional exhaustion, depersonalization, and reduced personal achievement (Wijaya I. M., 2020). Burnout is a complex phenomenon caused by biological factors in the work process and influenced by external and internal factors (Setyawati, 2010). Whereas Thomas, et al., in their journal, states that teacher's burnout is a severe psychological syndrome that can affect individual welfare and the function of the entire organization and harm the success of students (Thomas, Mukundan, \& Nimehchisalem, 2012). It can be concluded from the above definitions that burnout is a phenomenon in individuals as a response to mental, emotional, and physical fatigue, based on external and internal factors, and negatively impacts the overall function of the organization.

The world of education is one of the activities that has experienced the direct impact of COVID-19 pandemic. The learning interaction that was previously direct turned into Distance Learning (PJJ). This long-term condition causes teacher fatigue (burnout) caused by drastic changes in routine, reduced income, and lost warmth that usually exists with students. The consequences of teachers' burnout are felt by service recipients, namely students, their families, and the school itself. Burnout can be characterized by reduced or worsening performance and low productivity that causes conflict in work. Hanna explained the impact of burnout on the organization, the increased frequency of absences from work, quitting, or job turnover, so that it affects the organization's effectiveness and efficiency (Atmaja \& Suana, 2019). Teachers who have burnout at work usually begin an attitude of helplessness and have negative attitudes at work and others. Burnout has the following indicators: 1) emotional exhaustion, 2) depersonalization, 3) decreased achievement, 4) decreased personal achievement, and 5) personality changes (Ningsih, 2017).

The Education Assessment Center of the National Education Research and Development Agency stated that teachers' workload to educate, teach, guide, direct, or train a minimum of 24 hours a week. Besides the main task, teachers must also carry out other educational tasks, such as self-development activities, scientific publications, and innovative learning development. The total meantime of all academic assignments was 28.8 hours per week. Of the average 28.8 hours per week, $80-90 \%$ of the time work for the main activity of the teacher, planning lessons (12.50\%), carry out learning (52.80\%), and assessing student learning outcomes (15.60\%). The rest, $19.10 \%$ of total time to carry out extracurricular coaching (3.10\%), carry out tasks addition (12.10\%), and development profession (3.90\%). (Kamdi, 2014) The teacher's job description appears to be the workload when stated with units of time.

The workload is one factor that contributes to teacher burnout, where the excessive workload is the pressure of time. Each task is expected to be completed as quickly as possible, precisely, and carefully at certain times. The force of time causes many mistakes or causes a person's health condition to diminish (Munandar, 2014). The workload factor is a factor encountered by teachers in the work environment. Soeprihanto argues that a workload is a group or several activities that an organizational unit or an officeholder must complete within a certain period (Sumarni \& Soeprihanto, 2003). The workload can be defined as a difference between workers' capacity or ability and the job demands that must be faced (Astianto \& Suprihhadi, 2014). Meanwhile, the workload is the volume of work results or records of work results that can show the volume produced by several employees in a particular section (Moekijat, 2010). 
Therefore, teachers' capacity or ability and the demands of their work must be in line so that they do not become a workload and cause burnout. Workload indicators include: 1) continuous improvement in work, 2) quality improvement of work results, 3) attitudes towards employees, 4) understanding of primary substance about work, 5) work ethic, 6) behavior at work, 7) completing tasks which are challenging, 8) the physical conditions of the workplace, and attitudes towards time (Murti, 2013).

Apart from workload, compensation is also a factor that contributes to teacher's burnout. The workload felt by the teacher at work will increase because the compensation provided is not appropriate. Inaccurate compensation is caused by; (1) Providing less attractive types of compensation (2) Inappropriate rewards do not make teachers feel interested in getting them (Hernita, 2015). As a result, the teacher is bored with work.

Compensation is all income in the form of money or goods directly or indirectly received by employees in return for the company's services (Hasibuan, 2012). Besides, workers compensation can also be defined as everything an employee gets as remuneration for their work (Triyono, 2012). Compensation is indispensable for employees and teachers because one of the company's goals to provide employee welfare is to provide compensation to keep employees working (Rizal, Idrus, Djumahir, \& Mintarti, 2014).

A person's success influences compensation or success is influenced by various complementary factors. The compensation factor is a function of personal variables, situational variables, and the interaction between these variables (Nitisemito, 2014). The indicators for providing compensation for employees, of course, vary. In general, the hands of compensation are; 1) salary, 2) wages, 3) incentives, 4) allowances, and 5) facilities (Hasibuan, 2012).

The Alliance for Excellent Education in 2019 reports 17\% of teachers worldwide to quit within the first five years. In the United States alone, approximately half a million teachers leave the profession each year for job burnout. It causes a massive disruption as it creates $90 \%$ of the annual national demand for replacement of teachers leaving the work, requires reconsideration of the budget, and makes it difficult due to disruption of schools' stability.

Besides, Szabo and Jagodics' research that focuses on teachers' mental health reports high work burnout throughout the world's schools, for example, in Finland, Turkey, Canada, and the United States, with symptoms of a lack of enthusiasm in class and showing impatience and anxiety behaviour that worsens their performance (Szabo \& Jagodics, 2019).

The research was conducted to show that workload conditions and compensation contribute to teacher work burnout from the existing findings and facts. It is hoped that the research results will be helpful for understanding what needs to be prepared in managing and preventing teachers from the phenomenon of job burnout because the existence of teachers is essential in Indonesian's sustainability of education.

\section{METHODS}

This research uses a quantitative approach with multiple linear regression models. The research sample obtained using the Slovin formula with an error level of $5 \%$, so the research sample is 142 teachers in Cilacap Regency with a simple random sampling technique. The instrument that was distributed to respondents had previously tried out to validity and reliability test. This research was carried out by a closed questionnaire containing statements and alternative answers in a google form application. The questionnaire included 27 questions on the workload variable, 27 questions on the compensation variable, and 28 questions on the burnout variable. So, it has 82 questions on the questionnaire.

This research uses multiple linear regression models, which means several prerequisite tests for analysis include normality test, linearity test, multicollinearity test, and heteroscedasticity test. Multiple linear regression models are used to determine the contribution of variables X1 and $\mathrm{X} 2$ to variable $\mathrm{Y}$. Hypothesis testing will be carried out using the t-test and $\mathrm{F}$ test to determine the 
contribution between variables either partially or simultaneously. From this model, it will also be used for the value of the coefficient of determination because the value shows how much the independent variable influences the dependent variable. The application used to perform statistical calculations in this study is SPSS version 25.

The following hypotheses in this study: (1) Workload has a positive and significant contribution to teacher's burnout in Cilacap Regency; (2) Compensation contributes negatively and significantly to teacher's burnout in Cilacap Regency, and (3) Workload and compensation contribute together and significantly to teacher's burnout in Cilacap Regency.

\section{FINDINGS AND DISCUSSION}

\section{Analysis of Prerequisite Test}

1) Normality Test

By testing the normality using the Kolmogrov-Smirnov formula and using SPSS version 25 in the calculation, the Asymp. Sig. (2-tailed) value is 0.200 .

Table 1. Kolmogrov-Smirnov's Normality Test

\begin{tabular}{lll}
\hline & & $\begin{array}{l}\text { Unstandardized } \\
\text { Residual }\end{array}$ \\
\hline $\mathrm{N}$ & & 142 \\
Normal Parameters & Mean & 0,0000000 \\
& Std. Deviation & 10.83541260 \\
Most Extreme Differences & Absolute & 0.060 \\
& Positive & 0.060 \\
Test Statistic & Negative & -0.043 \\
Asymp. Sig. (2-tailed) & & 0.060 \\
\hline
\end{tabular}

Due to the Asymp. Sig. (2-tailed) value is $0.200>0.05$. It can be concluded that the data in this study were normally distributed.

2) Linearity Test

The linearity test is a test to prove a linear relationship between independent and dependent variables in research. In this research, there are two independent variables (workload and compensation) and one dependent variable (burnout). This linearity test was calculated using SPSS version 25, and the following results were obtained:

Table 2. Linearity Test: Workload on Burnout

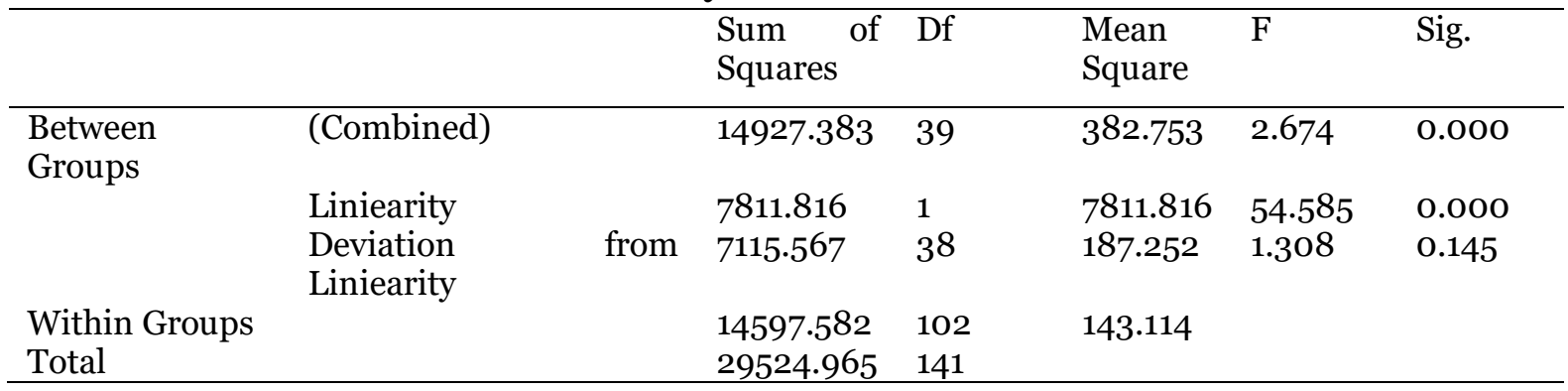

From the results above, it can be seen that the significance value of the workload variable $(\mathrm{X} 1)$ on the burnout variable $(\mathrm{Y})$ is 0.145 . Because of $0.145>0.05$, it can be concluded that there is a linear relationship between variables $\mathrm{X} 1$ and $\mathrm{Y}$. 


\section{Table 3. Linearity Test of Compensation on Burnout}

\begin{tabular}{|c|c|c|c|c|c|c|c|}
\hline & & & $\begin{array}{l}\text { Sum of } \\
\text { Squares }\end{array}$ & Df & $\begin{array}{l}\text { Mean } \\
\text { Square }\end{array}$ & $\mathrm{F}$ & Sig. \\
\hline \multirow{3}{*}{$\begin{array}{l}\text { Between } \\
\text { Groups }\end{array}$} & (Combined) & & 14815.688 & 41 & 361.358 & 2.457 & 0.000 \\
\hline & Liniearity & & 6968.563 & 1 & 6968.563 & 47.375 & 0.000 \\
\hline & $\begin{array}{l}\text { Deviation } \\
\text { Liniearity }\end{array}$ & from & 7847.125 & 40 & 196.178 & 1.334 & 0.126 \\
\hline Within Groups & & & 14709.277 & 100 & 147.093 & & \\
\hline Total & & & 29524.965 & 141 & & & \\
\hline
\end{tabular}

From the results above, it can be seen that the significance value of the compensation variable $(\mathrm{X} 2)$ on the burnout variable $(\mathrm{Y})$ is 0.126 . Because of $0.126>0.05$, it can be concluded that there is a linear relationship between variables $\mathrm{X} 2$ and $\mathrm{Y}$.

3) Multicollinearity Test

Multicollinearity test is used to find out whether there is a correlation between independent variables. A good regression model is a model that does not have multicollinearity symptoms with the condition that the Tolerance value is $>0.10$ and the VIF value $<10.00$. After the multicollinearity test was carried out using SPSS version 25, the following results were obtained:

Table 4. Multicollinearity Test

\begin{tabular}{|c|c|c|c|c|c|c|c|}
\hline & $\begin{array}{l}\text { Unstan } \\
\text { dardize } \\
\text { d } \\
\text { B } \\
\end{array}$ & $\begin{array}{l}\text { Coefficie } \\
\text { nts Std. } \\
\text { Error }\end{array}$ & $\begin{array}{l}\text { Standardi } \\
\text { zed } \\
\text { Coefficien } \\
\text { ts Beta }\end{array}$ & $\mathrm{t}$ & Sig. & $\begin{array}{l}\text { Collinea } \\
\text { rity } \\
\text { Toleran } \\
\text { ce }\end{array}$ & $\begin{array}{l}\text { Statisti } \\
\text { cs VIF }\end{array}$ \\
\hline (Constant) & 97.206 & 13.949 & & 6.969 & $\begin{array}{l}0.0 \\
\text { OO }\end{array}$ & & \\
\hline Workload & 0.642 & 0.090 & 0.455 & 7.099 & $\begin{array}{l}0.0 \\
00\end{array}$ & 0.980 & 1.020 \\
\hline Compensation & -0.560 & 0.085 & -0.422 & $\begin{array}{l}- \\
6.582\end{array}$ & $\begin{array}{l}0.0 \\
00\end{array}$ & 0.980 & 1.020 \\
\hline
\end{tabular}

From the results above, it can be seen that the tolerance value is $0.980>0.10$. It means that there are no symptoms of multicollinearity in this research. Besides, decisions can also be made by looking at the VIF value. Because the VIF value is $1.020<10.00$, it can be concluded that there are no multicollinearity symptoms in this research model.

4) Heteroscedasticity Test

A heteroscedasticity test is used to determine whether a regression model has a fixed residual value variance from one observation to another. The heteroscedasticity test in this study is to use the Rank Spearman test with the basis for decision making is if the significance value or Sig. (2-tailed) is bigger than 0.05, then there is no heteroscedasticity problem. After calculating using SPSS version 25, the following results were obtained:

Table 5. Heteroscedasticity Test

\begin{tabular}{|c|c|c|c|c|c|}
\hline & \multirow{2}{*}{$\begin{array}{l}\text { Unstand } \\
\text { ardized } \\
\text { B }\end{array}$} & Coefficient & \multirow{2}{*}{$\begin{array}{l}\text { Standardiz } \\
\text { ed } \\
\text { Coefficients } \\
\text { Beta }\end{array}$} & \multirow[t]{2}{*}{$\mathrm{t}$} & \multirow[t]{2}{*}{ Sig. } \\
\hline & & $\begin{array}{l}\text { S Std. } \\
\text { Error }\end{array}$ & & & \\
\hline (Constant) & -3.557 & 8.656 & & -0.411 & $\begin{array}{l}0.68 \\
2\end{array}$ \\
\hline \multirow{2}{*}{$\begin{array}{l}\text { Workload } \\
\text { Compensation }\end{array}$} & 0.046 & 0.056 & 0.069 & 0.815 & 0.417 \\
\hline & 0.070 & 0.053 & 0.113 & 1.332 & 0.185 \\
\hline
\end{tabular}


From the output above, it can be seen that the Sig. (2-tailed) for the workload is 0.417 , which is bigger $(>)$ than 0.05. Then, the Sig. (2-tailed) for compensation is 0.185, which is bigger ( $>$ ) than 0.05. Because the two significance values obtained are bigger than 0.05, it can be concluded that there is no heteroscedasticity problem in this regression model.

\section{Multiple Linear Regression Analysis}

After using SPSS version 25 to search for multiple linear regression models for this research, the following results were obtained:

Table 6. Multiple Linear Regression Analysis

\begin{tabular}{ll}
\hline Variable & $\begin{array}{l}\text { Regression } \\
\text { Coefficient }\end{array}$ \\
\hline Constant & 97.206 \\
Workload (X1) & 0.642 \\
Compensation (X2) & -0.560 \\
\hline
\end{tabular}

From the results, it can be concluded that the regression equation model in this research is: $\mathrm{Y}=97.206+0.642-0.560$. Then, it also has a coefficient of determination value from this equation:

Table 7. Coefficient of Determination Value

\begin{tabular}{clll}
\hline $\mathbf{R}$ & R Square & Adjusted R Square & $\begin{array}{l}\text { Std. Error } \\
\text { of the } \\
\text { Estimate }\end{array}$ \\
\hline 0.663 & 0.439 & 0.431 & 10.913 \\
\hline
\end{tabular}

From the results above, the coefficient of determination from this regression equation can be seen. The coefficient value shows how much influence the independent variable (X) has on the dependent variable $(\mathrm{Y})$ simultaneously. From the results obtained, it is known that the coefficient of determination is 0.439 or $43.9 \%$. It means that the workload variable (X1) and compensation variable (X2) contribute together to the burnout variable (Y) by $43.9 \%$. Meanwhile, the other $56.1 \%$ were influenced by other variables which were not researched.

\section{Hypothesis Test}

1) T-Test

Table 8. T-Test

\begin{tabular}{lll}
\hline Variable & t-count & Sig. \\
& & \\
\hline Workload (X1) & 7.099 & 0.000 \\
Compensation (X2) & -6.582 & 0.000 \\
\hline
\end{tabular}

From the results obtained, it can be seen that workload (X1) and compensation (X2) contribute to teacher's burnout partially (independently). It can be seen from the significance value of each independent variable. The significance of the workload variable is 0.000 , which is smaller $(<)$ than 0.05. Besides, the $t$ count for the workload variable is 7.099 , which is bigger $(>)$ than the $t$ (139) table, which is valued at 1.977. It can be concluded that the workload contributes to teacher's burnout. Compensation variable (X2) with a significance value of 0.000 which is also smaller $(<)$ than 0.05 . The t count of the compensation variable is $-6,582$ which is smaller $(<)$ than the $t$ (139) table, which is worth 1.977. A negative sign indicates a negative relationship between compensation and burnout. 


\section{2) F Test}

\section{Table 9. F Test}

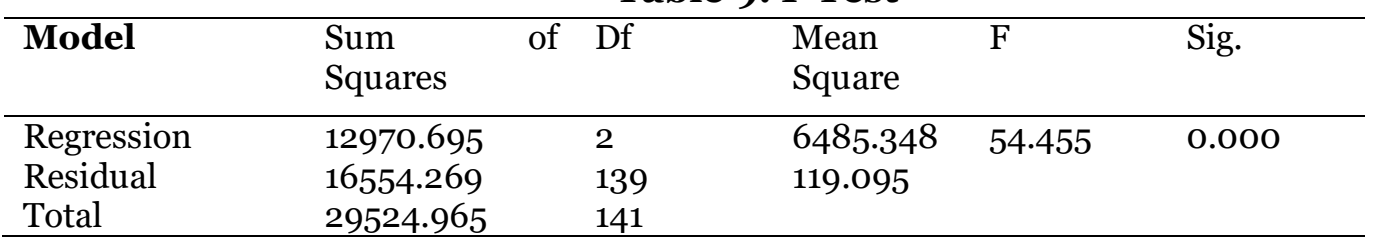

From the table, it can be seen that workload and compensation contribute to burnout simultaneously (together). It can be seen by looking at the significance value (Sig.), which is equal to 0.000 , which is smaller $(<)$ than 0.05 . Also, conclusions can be drawn by looking at the $\mathrm{F}$ calculate value. The $\mathrm{F}$ calculate value is 54,455 , which is bigger $(>)$ than the $\mathrm{F}(2,140)$ table, which is equal to 3.06. From these results, it can be concluded that workload and compensation simultaneously contribute to teacher's burnout. This can be seen from the significance value of the $\mathrm{F}$ test, it is 0.000 . This value is smaller $(<)$ than 0.05 , which means that there is a simultaneous (simultaneous) contribution of workload and compensation to teacher's burnout. The $\mathrm{F}$ calculate value, it is 54.455 , also bigger ( $>$ ) than the $\mathrm{F}$ table, which is valued at 3.06. The contribution by these two variables amounted to $43.9 \%$ towards teacher burnout. It is indicated by the value of $\mathrm{R} 2=0.439$. It can be concluded that the workload and compensation contribute together (simultaneously) and significantly to teacher burnout in Cilacap Regency, which means that this study's hypothesis is accepted.

It can also be seen that the workload contributes to teacher's burnout. It is shown by the significance value of $0.000<0.05$ and the $t$ count of $7.099>t$ (139) table of 1.977. These results are in line with Thakur's research in 2018, which stated that if the workload of teachers increases, then job burnout will increase. Workload causes burnout because it leads to high demand and low work performance, so that energy burns out and causes depersonalization (an indicator of burnout). Thus, schools in Pakistan must distribute a reasonable workload evenly among all teachers, improve facilities and promotions for teachers, and develop stress management measures to identify the level of teacher burnout. (Thakur, 2018).

Other studies conducted by Wijaya and Wibawa also stated that workload contributed positively to employee burnout. Excessive workload will cause feelings of pressure so that they feel unable to work correctly. They often feel like a failure and will cause burnout which will be a big problem for the organisation's management (Wijaya I. M., 2020). In this case, the school needs to clarify the workload that needs to be completed according to the job description so that the teacher is not overburdened, causing burnout. Research that Yusuf conducts conveyed that the workload factor was the strongest and contributed directly to the burnout of various work conditions. The level of difficulty and variety of work for which workers are responsible is higher so that it contributes to the perceived burnout (Yusuf, 2011). It means that if workers have an increased workload, then the perceived burnout is high.

The following results show that compensation also has a contribution to teacher work burnout. It is indicated by a significance value of $0.000<0.05$ and the $t$ count of $-6.582>t$ (139) table of 1.977. This result is supported by research conducted by Rahayu, in which the compensation variable predicted a decrease in employee burnout by $38.7 \%$. Companies are considered unable to provide welfare in unequal wages, benefits that are difficult to access, lack of facilities, and the role of superiors who are unable to respond to employee opinions. This causes employees to withdraw from job roles resulting in burnout (Rahayu A. D., 2019).

Long working hours and strict leave regulations are why employees experience burnout while working and result in employees wanting to find new jobs with a better compensation system (Rahayu \& Riana, 2017). From the research that has been done, it can be said that if the compensation received is low. The welfare will decrease and the results are reduced enthusiasm for doing work, and cause losses to the organization because goals are not achieved properly. 


\section{CONCLUSION}

The research results contribute positively to teacher burnout, but compensation contributes negatively to teacher burnout in Cilacap Regency. Schools in Cilacap Regency should pay attention to the workload given to teachers effectively and efficiently, also provide training and priority scale knowledge to teachers to increase their work power so that they can complete their assignments optimally and minimize burnout. The school should also provide compensation to teachers who are commensurate with the workload given. That way, the teacher will be motivated to carry out their work and decrease job burnout. This study still has weaknesses in its implementation because it is only limited to using the questionnaire technique in the google form application in the data collection process. Future researchers who will discuss similar matters may take more samples and include other variables not examined in this study.

\section{REFERENCES}

Astianto, A., \& Suprihhadi, H. (2014). Pengaruh Stres Kerja dan Beban Kerja terhadap Kinerja Karyawan PDAM Surabaya. Jurnal Ilmu dan Riset Manajemen, 3(7), 1-17. https://docplayer.info/43539706-Pengaruh-stres-kerja-dan-beban-kerja-terhadapkinerja-karyawan-pdam-surabaya.html

Atmaja, I. I., \& Suana, I. (2019). Pengaruh Beban Kerja Terhadap Burnout dengan Role Stress sebagai Variabel Mediasi pada Karyawan Rumours Restaurant. E-Jurnal Manajemen, 8(2), 7775-7804. doi:https://doi.org/10.24843/EJMUNUD.2019.v8.i2.p9

Hasibuan, M. (2012). Manajemen Sumber Daya Manusia. Jakarta: Bumi Aksara.

Moekijat. (2010). Sumber Daya Manusia. Bandung: CV Mandar Maju.

Munandar, A. S. (2014). Psikologi Industri dan Organisasi. Depok: UI Press.

Murti, S. (2013). Analisis Pengaruh Beban Kerja dan Kompensasi terhadap Produktivitas Kerja Guru SMP Negeri (Studi Kasus di SMP Negeri 5 Sragen). Jurnal Program Studi Manajemen Universitas Muhammadiyah Surakarta.

Ningsih, S. (2017). Pengaruh Kejenuhan Kerja, Beban Kerja dan Konflik Kerja terhadap Motivasi Kerja Perawat RSUD Dr. RM. Pratomo Bagan Siapiapi Kabupaten Rokan Hilir. JOM Fekon, 4(1), 495-509. Retrieved from: https://jom.unri.ac.id/index.php/JOMFEKON/article/view/12799/12441

Nitisemito, A. (2014). Manajemen Personalia. Jakarta: Ghalia Indonesia.

Rahayu, A. D. (2019). Hubungan antara Persepsi terhadap Kompensasi dengan Burnout pada Karyawan Restoran "X" Banjarnegara Jawa Tengah. Psikologi UMBY (pp. 48-58). Yogyakarta: eprints.mercubuana-yogya.ac.id. Retrieved from semanticscholar.org: https://www.semanticscholar.org/paper/BURNOUT-DITINJAU-DARI-PERSEPSITERHADAP-KOMPENSASIJuniarso/99bb8521a650c5deb1f28b4f138680880069bf6f\#related-papers

Rahayu, N. N., \& Riana, I. G. (2017). Pengaruh Kompensasi terhadap Kepuasan Kerja dan Keinginan Keluar pada Hotel Amaris Legian. E-Jurnal Manajemen Unud, 6(11), 58045833. Retrieved from https://ojs.unud.ac.id/index.php/Manajemen/article/view/32966

Rizal, M., Idrus, M., Djumahir, \& Mintarti, R. (2014). Effect of Compensation on Motivation, Organizational Commitment and Employee Performance (Studies at Local Revenue Management in Kendari City). International Journal of Business and Management Invention, 3(2), 64-79. Retrieved from http://www.ijbmi.org/papers/Vol(3)2/Version1/I0321064079.pdf

Setyawati. (2010). Selintas Tentang Kelelahan Kerja. Yogyakarta: Amara Books.

Sumarni, M., \& Soeprihanto, J. (2003). Pengantar Bisnis (Dasar-dasar Ekonomi Perusahaan). Yogyakarta: Liberty. 
Szabo, E., \& Jagodics, B. (2019). Teacher Burnout in the Light of Workplace, Organizational and Social Factors. HERJ (Hungarian Educational Research Journal), 9(3), 539-559. doi:10.1556/063.9.2019.3.44

Thakur, I. (2018). Relationship between Workload and Burnout of Special Education Teachers. Pakistan Journal of Distance \& Online Learning, 4(1), 235-242. Retrieved from https://eric.ed.gov/?id=EJ1267092

Thomas, N. S., Mukundan, J., \& Nimehchisalem, V. (2012, September). Burnout among Low and High Experienced Teachers. International Journal of Applied Linguistics \& English Literature, 1(4), 24-29. doi:10.7575/ijalel.v.1n.4p.24

Triyono, A. (2012). Manajemen SDM. Jakarta: Oryza.

Wardhani, D. T. (2012, April). Burnout di Kalangan Guru Pendidikan Luar Biasa di Kota Bandung. Jurnal Psikologi Undip, 11(1), 73-82. doi:https://doi.org/10.14710/jpu.11.1.10

Wijaya, I. A., \& Wibawa, I. A. (2020). Beban Kerja Berpengaruh terhadap Burnout dengan Variabel Work Family Conflict sebagai Pemediasi. E-Jurnal Manajemen, 9(2), 597-616. doi:DOI: https://doi.org/10.24843/EJMUNUD.2020.vo9.io2.p10

Wijaya, I. A., \& Wibawa, I. A. (2020). Beban Kerja Berpengaruh Terhadap Burnout dengan Variabel Work Family Conflict sebagai Pemediasi. E-Jurnal Manajemen, 9(2), 597-616. doi:https://doi.org/10.24843/EJMUNUD.2020.v09.io2.p10

Wijaya, I. M. (2020). Beban Kerja Berpengaruh Terhadap Burnout dengan Variabel Work Family Conflict sebagai Pemediasi. E-Jurnal Manajemen, 9(2), 597-616. doi:DOI: https://doi.org/10.24843/EJMUNUD.2020.v09.io2.p10

Yusuf, H. (2011). Pengaruh Kondisi Organisasi terhadap Kejenuhan Kerja Pekerja Sosial yang Bekerja di Panti Sosial Penyandang Cacat di Indonesia. Jurnal Sosio Informa, 16(3), 177-187. doi:https://doi.org/10.33007/inf.v16i3.49 